\title{
SEISMIC RESPONSE OF TRANSMISSION TOWER - A CASE STUDY
}

\author{
Tejaswini $\mathbf{G}^{1}$, Subramanya $\mathbf{P ~ G}^{2}$ \\ ${ }^{\text {l} C i v i l ~ E n g g . ~ D e p a r t m e n t, ~ V i s w e s w a r a i a h ~ T e c h n o l o g i c a l ~ U n i v e r s i t y, ~ A s s i s t a n t . ~ P r o f e s s o r, ~ G o v t . ~ E n g g . ~ C o l l e g e, ~}$ \\ Ramanagara, Bangalore, Karnataka, India, tejas.dvg@gmail.com \\ ${ }^{2}$ Civil Engg. Department, Visweswaraiah Technological University, Assistant. Professor, S J M Institute of \\ Technology, Chitradurga, Karnataka, India, mani9meena@gmail.com
}

\begin{abstract}
Towers and tower like structures are the major infrastructure for the transmission of electrical power, telecommunication and broadcasting. The transmission towers are highly repetitive and therefore the analysis and designs should be highly competitive towards commercial solutions. In the present study, an attempt has been made to analyse the existing Electrical Transmission tower of voltage $220 \mathrm{kV}$ using FEM software NISA. The analysis of an existing structure without secondary bracings has been carried out for the North-South Component of EL-Centro Ground motion, 1940.In this analysis, the stiffness and damping properties have been considered for improving the seismic performance of the existing structure. By keeping the Group number as it is, using different sections, the geometric properties of the given angle section are optimized to optimized angle section and optimized tubular section. For cross braces, the damping value is varied ranging from 5\%-25\% for above sections. In this analysis, the displacement at top cross-arm of the tower is considered as the main parameter for conservative results. Finally the results obtained are regarding possible improvements in the analysis of the existing structure
\end{abstract}

\section{INTRODUCTION}

Electric power today plays an important role in the life of the community and the development of various sectors of economy and also during the earthquake. Developing countries like India are therefore giving a high priority to power development programmes. In fact, the economy is becoming increasingly dependent on electricity as a basic input.

Many transmission towers suffer severe damage as a result of natural disasters (particularly high intensity earthquakes and hurricanes), electric power fail within minutes of the earthquake, leading to the partial or total collapse of the structures and the interruption of the transmission services urgently needed by the victims of the event. Earthquakes can cause considerable damage to structures, especially among older structures that were built to less stringent seismic design codes.

It is in this context, the Transient dynamic analysis of the transmission tower is done. The Transmission towers must be reoriented towards disaster mitigation, with the ultimate goal, not only reducing the deflection of the structure, but also optimizing the structure using different sections against disaster strikes.

\section{ANALYSIS OF TRANSMISSION TOWER}

\subsection{Methodology}

Structural analysis is concerned with modelling of structural behaviour, where the model is mathematical rather than physical. In the present study, selected Electrical Transmission Tower consists of leg members, cross-braces, secondary bracings and cross arms as its components. The secondary bracings are not considered in the analysis due to limitation of available software. Using NISA software the Transmission tower is modelled. The analysis has been done for the same Height/Length ratio, same base width and same loading conditions for the tower with different types of sections and different percentage of damping to the bracing system of the transmission tower at different stories or combination of stories.

\subsection{A Case Study of an Existing Structure}

Here an attempt is made to analyse the existing Transmission tower structure without secondary bracings under seismic loading condition but actually the existing Transmission tower has secondary bracings which is as shown in fig1. The type of analysis adopted for the analysis of Transmission tower is Transient Dynamic Analysis. In the present analysis, North-South component of EL-Centro ground motion (1940) is used as support excitation. It consists of 1559 data points each at an equal time spacing of $0.02 \mathrm{sec}$. The number of modes considered in this analysis is 20 and the damping value provided for the structure is $2 \%$ ( for steel).

In this analysis different sections and different damping values $(5 \%-25 \%)$ varied up to three stories only, from the bottom of the tower. 

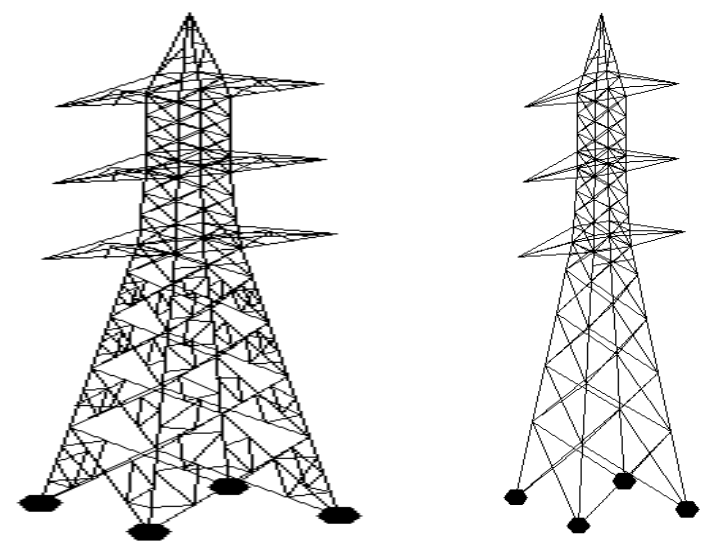

Fig 1: 3D-View of Transmission Tower with Secondary bracings and without secondary bracings

The following tables provide the information regarding Material and Sectional properties taken for the analysis.

Table 1: Material Properties

\begin{tabular}{|c|c|c|c|}
\hline $\begin{array}{l}\text { Material } \\
\text { ID }\end{array}$ & $\begin{array}{l}\text { Density in } \\
\mathrm{kg} / \mathrm{m}^{3}\end{array}$ & $\begin{array}{l}\text { Elastic } \\
\text { modulus } \\
\mathrm{N} / \mathrm{mm}^{2}\end{array}$ & $\begin{array}{l}\text { Poisson's } \\
\text { ratio }\end{array}$ \\
\hline 1 & 7850 & $2 \mathrm{xE} 05$ & 0.3 \\
\hline
\end{tabular}

Table 2: Sectional Properties For A Given Angle For Different Sections

\begin{tabular}{|c|c|c|c|}
\hline \multirow{2}{*}{$\begin{array}{l}\text { Group } \\
\text { number }\end{array}$} & \multicolumn{3}{|c|}{$\begin{array}{l}\text { Sectional area in } \mathrm{mm}^{2} \text {, for different } \\
\text { sections }\end{array}$} \\
\hline & $\begin{array}{l}\text { Given angle } \\
\text { section }\end{array}$ & $\begin{array}{l}\text { Optimized } \\
\text { angle section }\end{array}$ & $\begin{array}{l}\text { Optimized } \\
\text { tubular } \\
\text { section }\end{array}$ \\
\hline 1 & 1164 & 5076 & 6898 \\
\hline 2 & 1044 & 2900 & 5890 \\
\hline 3 & \begin{tabular}{|l|}
924 \\
\end{tabular} & 2700 & 4825 \\
\hline 4 & 625 & 2300 & 3769 \\
\hline 5 & 525 & 1056 & 923.6 \\
\hline 6 & 384 & 384 & 1055 \\
\hline 7 & 344 & 896 & 1306 \\
\hline 8 & 725 & 1856 & 3455 \\
\hline 9 & 675 & 1536 & 3141 \\
\hline
\end{tabular}

\subsection{Response of Structure}

The response helps us for the assessment of performance and structural stability of structure under dynamic loads. The response considered in this analysis is the Displacement. According to code-book IS: 802 (part-3), the Tower deflections under load shall be measured by suitable procedure at the top cross-arm level on the front sides of the transverse and longitudinal faces are front and rear sides of transverse faces.
In this analysis just we tried to observe, how much we can reduce the deflection using different types sections and also using different percentage of damping values @ different storeys as shown in fig 2 .


Fig 2: Dampers to the cross-braces at different stories \& combination of story

\section{RESULTS AND DISCUSSION}

\subsection{Displacement of Transmission Tower At Top}

\section{Cross-Armlevel For Different Sections:}

In the present Analysis, we have considered the displacement of Transmission tower at top cross-arm level as the main parameter. Table 3 shows the percentage change of the displacements are with respect to displacement of existing structure, which is taken as the datum value for all comparisons and the graphs plotted are shown in fig 3. Optimized tubular section with X-bracing shows good reduction in the displacement compare to other two sections.

Table 3. Comparison of displacement of transmission tower at cross-armlevel for different sections.

\begin{tabular}{|c|c|c|}
\hline $\begin{array}{l}\text { Different } \\
\text { Sections }\end{array}$ & $\begin{array}{l}\text { Displacement, } \\
\text { mm }\end{array}$ & $\%$ Change \\
\hline Given angle & 764.25 & 0.00 \\
\hline $\begin{array}{l}\text { Optimized } \\
\text { angle }\end{array}$ & 571.25 & -25.23 \\
\hline $\begin{array}{l}\text { Optimized } \\
\text { tubular }\end{array}$ & 548.27 & -28.23 \\
\hline
\end{tabular}




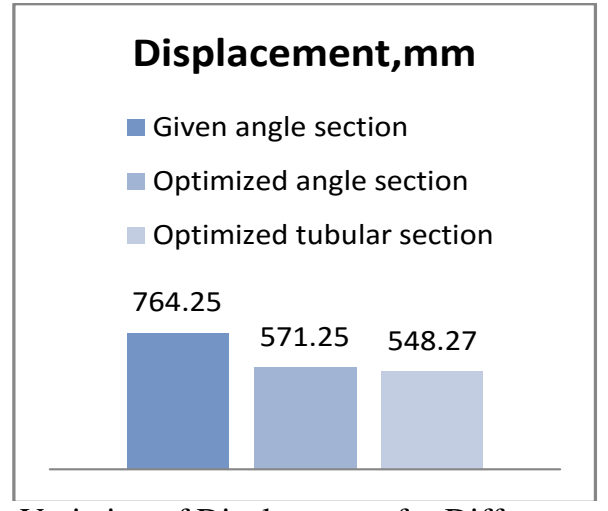

Fig 3: Variation of Displacement for Different sections

\subsection{Effect of Damping of Cross-Braces}

Here different damping values are given to the cross braces @ different stories \& combinations like $1^{\text {st }}$ storey, $2^{\text {nd }}$ storey, $3^{\text {rd }}$ storey, $1^{\text {st }}$ and $2^{\text {nd }}$ storey, $2^{\text {nd }}$ and $3^{\text {rd }}$ storey, $1^{\text {st }}$ and $3^{\text {rd }}$ storey, and $1^{\text {st }}, 2^{\text {nd }}$ and $3^{\text {rd }}$ storey.

By providing different damping values $(5 \%-25 \%)$ of the cross-braces, the displacement of the structure shows good reduction in the displacement as the damping value increases. Table 4 - Table 10 shows the percentage reduction in the displacement for different sections in comparison with the displacement value of existing structure, which is taken as the datum value $(764.25 \mathrm{~mm})$. The variations in the displacement value for different sections are shown in the Fig 4 - Fig 10.

Table 4: Comparison of displacements for different sections with different damping value of cross-braces given at $1^{\text {st }}$ storey

\begin{tabular}{|c|c|c|c|c|c|c|c|c|c|c|c|c|}
\hline \multirow{3}{*}{$\begin{array}{l}S l \\
\text { no }\end{array}$} & \multirow{3}{*}{ Sections } & \multicolumn{11}{|c|}{ Displacement in $\mathrm{mm}$} \\
\hline & & \multirow[b]{2}{*}{$\begin{array}{l}\text { Datum } \\
\text { Value }\end{array}$} & \multicolumn{10}{|c|}{ Percent damping of cross-braces } \\
\hline & & & $5 \%$ & $\begin{array}{c}\% \\
\text { change }\end{array}$ & $10 \%$ & $\begin{array}{c}\% \\
\text { change }\end{array}$ & $15 \%$ & $\begin{array}{c}\% \\
\text { change }\end{array}$ & $20 \%$ & $\begin{array}{c}\% \\
\text { change }\end{array}$ & $25 \%$ & $\begin{array}{c}\% \\
\text { Change }\end{array}$ \\
\hline 1 & $\begin{array}{l}\text { Given } \\
\text { angle }\end{array}$ & \multirow{3}{*}{764} & 783.72 & +2.58 & 775.66 & +1.51 & 778.68 & +1.8 & 781.37 & +2.22 & 783.02 & +2.48 \\
\hline 2 & $\begin{array}{l}\text { Optimized } \\
\text { angle }\end{array}$ & & 573.18 & -24.9 & 574.34 & -24.8 & 573.73 & -24.9 & 572.05 & -25.1 & 569.74 & -25.4 \\
\hline 3 & $\begin{array}{l}\text { Optimized } \\
\text { tubular }\end{array}$ & & 547.04 & -28.4 & 545.85 & -28.5 & 548.05 & -28.2 & 550.24 & -27.9 & 552.48 & -27.6 \\
\hline
\end{tabular}

NOTE: ' + ' $=$ Increase; ' $-`=$ Decrease, Datum value taken for the $\%$ change is the displacement value of existing structure

Table 5: Comparison of displacements for different sections with different damping value of cross-braces given at $2^{\text {nd }}$ storey

\begin{tabular}{|c|c|c|c|c|c|c|c|c|c|c|c|c|}
\hline \multirow{3}{*}{$\begin{array}{l}\text { Sl } \\
\text { no }\end{array}$} & \multirow{3}{*}{ Sections } & \multicolumn{11}{|c|}{ Displacement in $\mathrm{mm}$} \\
\hline & & \multirow[b]{2}{*}{$\begin{array}{l}\text { Datum } \\
\text { Value }\end{array}$} & \multicolumn{10}{|c|}{ Percent damping of cross-braces } \\
\hline & & & $5 \%$ & $\begin{array}{c}\% \\
\text { change }\end{array}$ & $10 \%$ & $\begin{array}{c}\% \\
\text { change }\end{array}$ & $15 \%$ & $\begin{array}{c}\% \\
\text { change }\end{array}$ & $20 \%$ & $\begin{array}{c}\% \\
\text { change }\end{array}$ & $25 \%$ & $\begin{array}{c}\% \\
\text { Change }\end{array}$ \\
\hline 1 & Given angle & \multirow{3}{*}{764} & 769.4 & +0.7 & 767.75 & +0.48 & 766.06 & +0.26 & 763.21 & -0.10 & 762.84 & -0.15 \\
\hline 2 & $\begin{array}{c}\text { Optimized } \\
\text { angle }\end{array}$ & & 567.31 & -25.7 & 554.4 & -27.4 & 548.08 & -28.2 & 541.84 & -29.0 & 536.81 & -29.8 \\
\hline 3 & $\begin{array}{l}\text { Optimized } \\
\text { tubular }\end{array}$ & & 544.73 & -28.7 & 540.32 & -29.2 & 538.75 & -29.4 & 537.19 & -29.6 & 536.37 & -29.7 \\
\hline
\end{tabular}

Table 6: Comparison of displacements for different sections with different damping value of cross-braces given at $3^{\text {rd }}$ storey

\begin{tabular}{|c|c|c|c|c|c|c|c|c|c|c|c|c|}
\hline \multirow{3}{*}{$\begin{array}{l}\text { Sl } \\
\text { no }\end{array}$} & \multirow[b]{3}{*}{ Sections } & \multicolumn{11}{|c|}{ Displacement in mm } \\
\hline & & \multirow[b]{2}{*}{$\begin{array}{l}\text { Datum } \\
\text { Value }\end{array}$} & \multicolumn{10}{|c|}{ Percent damping of cross-braces } \\
\hline & & & $5 \%$ & $\begin{array}{c}\% \\
\text { change }\end{array}$ & $10 \%$ & $\begin{array}{c}\% \\
\text { change }\end{array}$ & $15 \%$ & $\begin{array}{c}\% \\
\text { change }\end{array}$ & $20 \%$ & $\begin{array}{c}\% \\
\text { change }\end{array}$ & $25 \%$ & $\begin{array}{c}\% \\
\text { Change }\end{array}$ \\
\hline 1 & $\begin{array}{l}\text { Given } \\
\text { angle }\end{array}$ & \multirow{3}{*}{764} & 770.42 & +0.84 & 770.5 & +0.85 & 770.57 & +0.86 & 770.63 & +0.87 & 763.65 & -0.05 \\
\hline 2 & $\begin{array}{l}\text { Optimized } \\
\text { angle }\end{array}$ & & 569.24 & -25.5 & 565.04 & -25.98 & 561.45 & -26.51 & 557.3 & -27 & 553.18 & -27.6 \\
\hline 3 & $\begin{array}{l}\text { Optimized } \\
\text { tubular }\end{array}$ & & 547.24 & -28.37 & 545.52 & -28.59 & 543.81 & -28.82 & 544.10 & -28.78 & 544.42 & -28.74 \\
\hline
\end{tabular}


Table 7: Comparison of displacements for different sections with different damping value of cross-braces given at $1^{\text {st }}$ and $2^{\text {nd }}$ storey

\begin{tabular}{|c|c|c|c|c|c|c|c|c|c|c|c|c|}
\hline \multirow{3}{*}{$\begin{array}{l}\text { Sl } \\
\text { no }\end{array}$} & \multirow{3}{*}{ Sections } & \multicolumn{11}{|c|}{ Displacement in mm } \\
\hline & & \multirow{2}{*}{$\begin{array}{l}\text { Datum } \\
\text { Value }\end{array}$} & \multicolumn{10}{|c|}{ Percent damping of cross-braces } \\
\hline & & & $5 \%$ & $\begin{array}{c}\% \\
\text { change }\end{array}$ & $10 \%$ & $\begin{array}{c}\% \\
\text { change }\end{array}$ & $15 \%$ & $\begin{array}{c}\% \\
\text { change }\end{array}$ & $20 \%$ & $\begin{array}{c}\% \\
\text { change }\end{array}$ & $25 \%$ & $\begin{array}{c}\% \\
\text { Change }\end{array}$ \\
\hline 1 & $\begin{array}{l}\text { Given } \\
\text { angle }\end{array}$ & \multirow{3}{*}{764} & 771.47 & 97 & 772.82 & 5 & 763.54 & -0.06 & 762.24 & -0.23 & 760.86 & -0.41 \\
\hline 2 & $\begin{array}{l}\text { Optimized } \\
\text { angle }\end{array}$ & & 568.66 & -25.56 & 562.49 & -26.37 & 554.97 & -27.35 & 546.87 & -28.42 & 538.61 & -29.50 \\
\hline 3 & $\begin{array}{l}\text { Optimized } \\
\text { tubular }\end{array}$ & & 543.54 & -28.85 & 543.37 & -28.87 & 540.97 & -29.19 & 544.54 & -28.72 & 545.09 & -28.65 \\
\hline
\end{tabular}

Table 8: Comparison of displacements for different sections with different damping value of cross-braces given at $2^{\text {nd }}$ and $3^{\text {rd }}$ storey

\begin{tabular}{|c|c|c|c|c|c|c|c|c|c|c|c|c|}
\hline \multirow{3}{*}{$\begin{array}{l}\text { Sl } \\
\text { no }\end{array}$} & \multirow{3}{*}{ Sections } & \multicolumn{11}{|c|}{ Displacement in $\mathrm{mm}$} \\
\hline & & \multirow{2}{*}{$\begin{array}{l}\text { Datum } \\
\text { Value }\end{array}$} & \multicolumn{10}{|c|}{ Percent damping of cross-braces } \\
\hline & & & $5 \%$ & $\begin{array}{c}\% \\
\text { change }\end{array}$ & $10 \%$ & $\begin{array}{c}\% \\
\text { change }\end{array}$ & $15 \%$ & $\begin{array}{c}\% \\
\text { change }\end{array}$ & $20 \%$ & $\begin{array}{c}\% \\
\text { change }\end{array}$ & $25 \%$ & $\begin{array}{c}\% \\
\text { Change }\end{array}$ \\
\hline 1 & $\begin{array}{l}\text { Given } \\
\text { angle }\end{array}$ & \multirow{3}{*}{764} & 769.35 & +0.69 & 767.59 & +0.45 & 765.78 & +0.19 & 763.93 & -0.01 & 762.22 & -0.24 \\
\hline 2 & $\begin{array}{l}\text { Optimized } \\
\text { angle }\end{array}$ & & 564.71 & -26.08 & 554.32 & -27.44 & 544.50 & -28.73 & 535.23 & -29.94 & 526.45 & -31.09 \\
\hline 3 & $\begin{array}{c}\text { Optimized } \\
\text { tubular }\end{array}$ & & 543.70 & -28.83 & 540.85 & -29.20 & 539.64 & -29.36 & 538.21 & -29.55 & 536.87 & -29.73 \\
\hline
\end{tabular}

Table 9: Comparison of displacements for different sections with different damping value of cross-braces given at $1^{\text {st }}$ and $3^{\text {rd }}$

\begin{tabular}{|c|c|c|c|c|c|c|c|c|c|c|c|c|}
\hline \multirow{4}{*}{$\begin{array}{l}\text { Sl } \\
\text { no }\end{array}$} & & & & & & storey & & & & & & \\
\hline & \multirow{3}{*}{ Sections } & \multicolumn{11}{|c|}{ Displacement in $\mathbf{m m}$} \\
\hline & & \multirow{2}{*}{$\begin{array}{c}\text { Datum } \\
\text { Value }\end{array}$} & \multicolumn{10}{|c|}{ Percent damping of cross-braces } \\
\hline & & & $5 \%$ & $\begin{array}{c}\% \\
\text { change }\end{array}$ & $10 \%$ & $\begin{array}{c}\% \\
\text { change }\end{array}$ & $15 \%$ & $\begin{array}{c}\% \\
\text { change }\end{array}$ & $20 \%$ & $\begin{array}{c}\% \\
\text { change }\end{array}$ & $25 \%$ & $\begin{array}{c}\% \\
\text { Change }\end{array}$ \\
\hline 1 & $\begin{array}{c}\text { Given } \\
\text { angle }\end{array}$ & \multirow{3}{*}{764} & 772.44 & +1.04 & 775.46 & +1.43 & 778.40 & +1.83 & 780.91 & +2.2 & 783.27 & +2.5 \\
\hline 2 & $\begin{array}{c}\text { Optimized } \\
\text { angle }\end{array}$ & & 570.12 & -25.37 & 569.02 & -25.52 & 565.53 & -25.97 & 561.40 & -26.51 & 557.08 & -27.08 \\
\hline 3 & $\begin{array}{c}\text { Optimized } \\
\text { tubular }\end{array}$ & & 546.02 & -28.53 & 546.37 & -28.48 & 548.75 & -28.17 & 551.16 & -27.85 & 553.57 & -27.54 \\
\hline
\end{tabular}

Table 10: Comparison of displacements for different sections with different damping value of cross-braces given at $2^{\text {nd }}$ and $3^{\text {rd }}$ storey

\begin{tabular}{|c|c|c|c|c|c|c|c|c|c|c|c|c|}
\hline \multirow{3}{*}{$\begin{array}{l}\text { Sl } \\
\text { No }\end{array}$} & \multirow{3}{*}{ Sections } & \multicolumn{11}{|c|}{ Displacement In Mm } \\
\hline & & \multirow{2}{*}{$\begin{array}{l}\text { Datum } \\
\text { Value }\end{array}$} & \multicolumn{10}{|c|}{ Percent Damping Of Cross-Braces } \\
\hline & & & $5 \%$ & $\begin{array}{c}\% \\
\text { Change }\end{array}$ & $10 \%$ & $\begin{array}{c}\% \\
\text { Change }\end{array}$ & $15 \%$ & $\begin{array}{c}\% \\
\text { Change }\end{array}$ & $20 \%$ & $\begin{array}{c}\% \\
\text { Change }\end{array}$ & $25 \%$ & $\begin{array}{c}\% \\
\text { Change }\end{array}$ \\
\hline 1 & $\begin{array}{l}\text { Given } \\
\text { Angle }\end{array}$ & \multirow{3}{*}{764} & 770.41 & +0.83 & 772.47 & +1.1 & 763.15 & -0.11 & 761.26 & -0.36 & 760.03 & -0.52 \\
\hline 2 & $\begin{array}{c}\text { Optimized } \\
\text { Angle }\end{array}$ & & 555.03 & -27.35 & 529.06 & -30.75 & 524.22 & -31.38 & 512.81 & -32.87 & 506.03 & -33.76 \\
\hline 3 & $\begin{array}{c}\text { Optimized } \\
\text { Tubular }\end{array}$ & & 538.18 & -29.55 & 529.10 & -30.74 & 505.29 & -33.86 & 499.13 & -34.66 & 493.18 & -35.44 \\
\hline
\end{tabular}




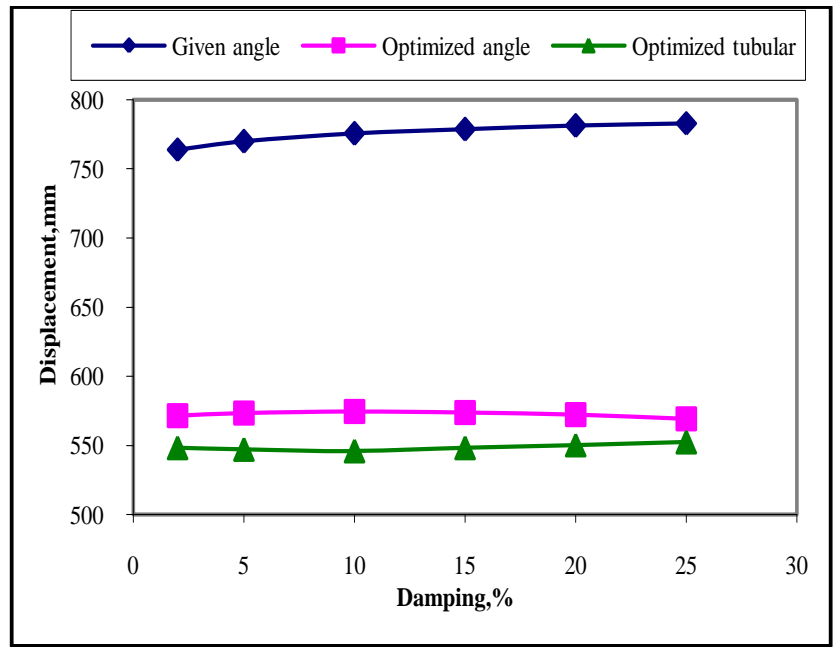

Fig 4: Displacement for different damping value given at cross- braces at $1^{\text {st }}$ storey



Fig 5: Displacement for different damping value given at cross- bracesat $2^{\text {nd }}$ storey

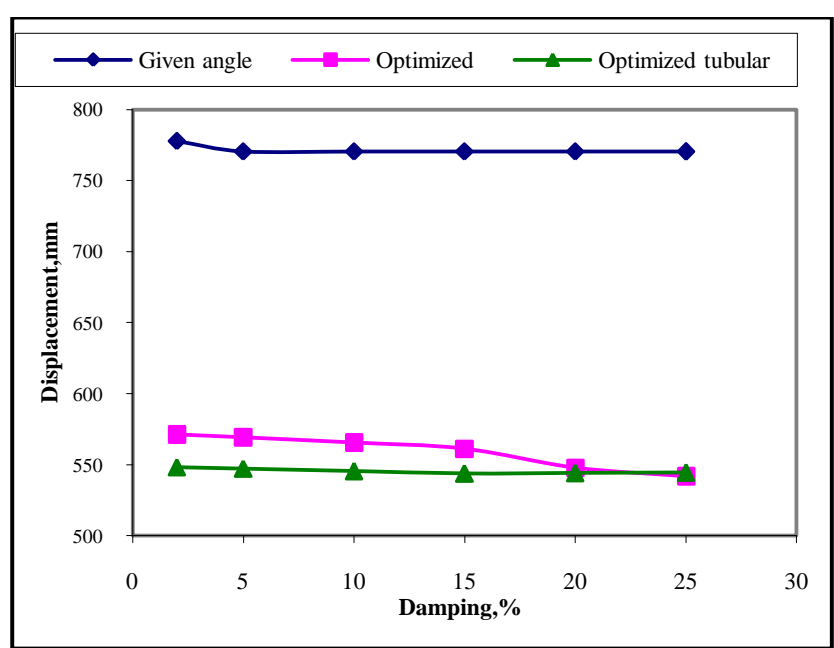

Fig 6: Displacement for different damping value given at cross- bracesat $3^{\text {rd }}$ storey



Fig 7: Displacement for different damping value given at cross- bracesat $1^{\text {st }} \& 2^{\text {nd }}$ storey

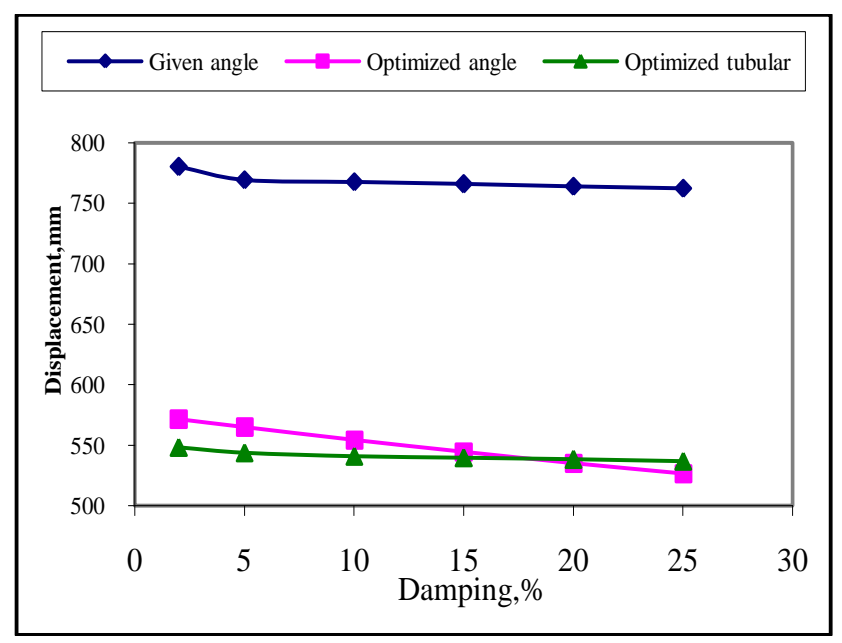

Fig 8: Displacement for different damping value given at cross- braces at 2 nd storey $\& 3^{\text {rd }}$ storey

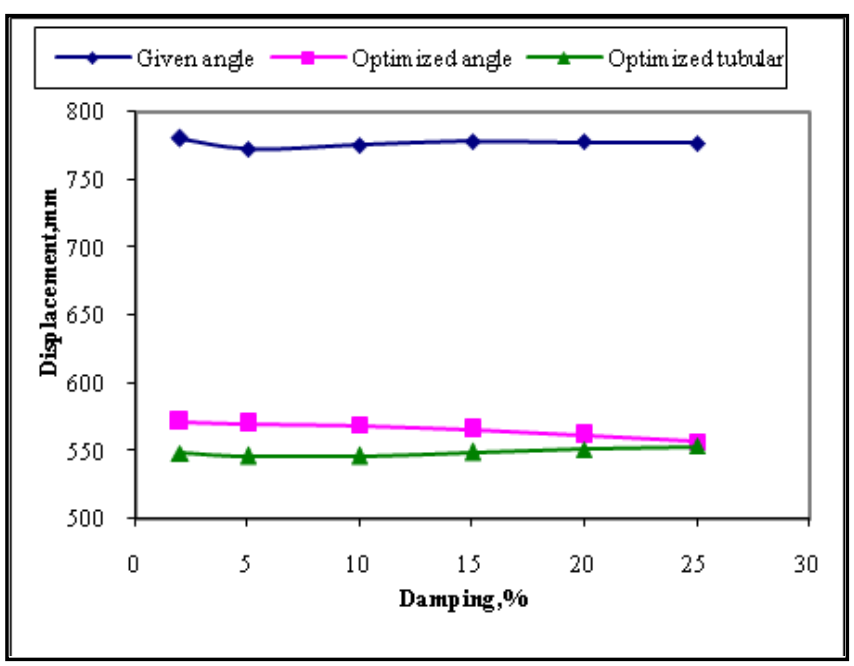

Fig 9: Displacement for different damping value given at cross- braces at 1 st storey $\& 3^{\text {rd }}$ storey 


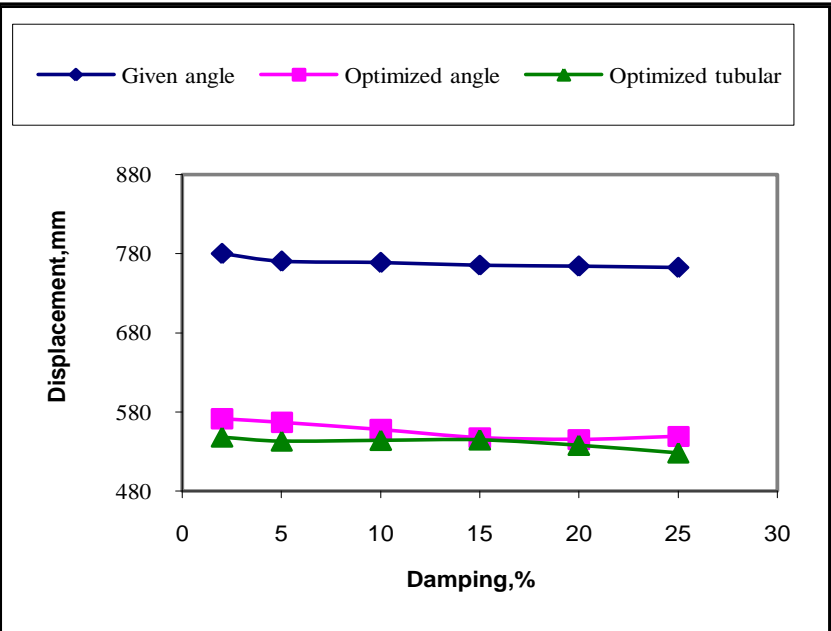

Fig 10: Displacement for different damping value given at cross- braces At $1^{\text {st }}, 2^{\text {nd }} \& 3^{\text {rd }}$ storey

\section{CONCLUSIONS}

From the present study of Analysis of Existing Transmission Tower, it is observed that optimized tubular section with Xbracing system shows maximum decrease in the displacement (-28.23\%) compared to other two sections (Given angle \& Optimized angle). And also it is observed that, on adding different damping value to the cross-braces (X-bracing), the Transmission tower shows maximum decrease in the displacement $(-35.44 \%)$ for optimized tubular section where $25 \%$ damping value given at $1^{\text {st }}, 2^{\text {nd }}$ and $3^{\text {rd }}$ storey compared to other two sections (Given angle $\&$ Optimized angle).

\section{REFERENCES}

[1]. Anil K Chopra, "Structural Dynamics", Pearson Edition.

[2]. Jonathan Dowell L \& Sudha Maheshwari, "Simulating Earthquake Damage to the ElectricPower Infrastructure: A Case Study for Urban Planning and Policy Development", ljdowell@lanl.gov. (2000).

[3]. Lakshmipathy M., "Analysis and Design of Transmission Line Towers", I.S.T.E Summer School, Indian Society for Technical Education, New Delhi, (1990).

[4]. Prasada Rao N., S.J. Mohan, N. Lakshmanan, "Lessons from Premature failure of Cross arms in transmission line towers during Prototype testing", Structural Engineering Research Centre, CSIR Campus, TTTI, India, (2001).

[5]. Syal I.C. \& Santinder Singh "Design Of Steel Structures", First Edition, Tata McGraw-Hill, Delhi, pp.526-549, (2000).

[6]. Vazirani V.N., Ratwani M.M. \& Honey Mehta "Design \& Analysis Of Steel Structures", Seventeenth Edition, Khanna Publushers, New Delhi, pp.874 - 881, (2000).

[7]. Xiaojing LI, Linlin GE, Gang-Ding PENG, "Seismic Response of a Tower as Measured by an Integrated RTK-GPS System", $1^{\text {st }}$ FIG International symposium on Engineering surveys for construction works and structural engineering Nottingham, United Kingdom, 28 june-1 July, pp. 1-17, (2004).

[8]. Ying-Hui Lei* and Yu-Lin Chien, "Seismic Analysis of Transmission Towers Considering Both Geometric and Material Nonlinearities", Tamkang Journal of Science and Engineering, Vol. 8, No 1, pp. 29 - 42, (2005).

[9]. IS: 801 (Part I/ Sec I) - 1995, "Code of Practice for use of Structural Steel in Overhead Transmission Line Towers", ISI, New Delhi

[10]. IS: 802 (Part III) - 1978, "Code of Practice for use of Structural Steel in Overhead Transmission Line Towers", ISI, New Delhi 